\title{
Judicial Limitation of Three-Judge Court Jurisdiction
}

Congress enacted the Three-Judge Court Act ${ }^{\mathcal{I}}$ in 1910 to restrict interference by federal courts with the operation of state statutes. Refusing to withdraw all federal court power to enjoin the enforcement of state legislation, 2 Congress established procedures governing the issuance of injunctions to protect state laws from "improvident state-wide doom" at the hands of a single district judge." Under the Act, three judges, including one circuit judge, must hear and determine applications to enjoin enforcement of state statutes "upon the ground of unconstitutionality." 4 Their determination is appealable directly to the Supreme Court."

The requirement of a three-judge court was designed to reduce the chance that a state statute would be invalidated by the caprice or bias of a single judge. ${ }^{6}$ The right of direct review was intended to shorten the period of time during which an injunction erroneously granted would remain in effect. ${ }^{i}$ Originally the Three-Judge Court

1. Act of June 18, 1910, ch. 309, \$ 17, 36 Stat. 557 (current version at 28 U.S.C. $\$ \$ 2281,2284,1253(1970))$. The Act was passed in response to the Supreme Court's decision in Ex parte Young, 209 U.S. 123 (1908), upholding an injunction issucd by a district judge against the enforcement of a Minnesota railroad rate statute. The atlthoritative article on three-judge courts is Currie, The Three-Judge District Coutrt in Constitutional Litigation, 32 U. CHI. L. REv. I (1964). For a summary of the background of and amendments to the Act, see P. Bator, P. Mishin, D. Shapiro \& H. Wechsler, Hart and Wechsler's The Federal Courts and the Federal System 967-76 (2d ed. 1973) [hereinafter cited as HART AND WechSLER].

2. In 1908 Senator Lee S. Overman submitted a bill denying federal courts the power to enjoin state statutes. In 1910 a similar bill was passed by the House but failed in the Senate. Currie, supra note 1 , at $6 \&$ n.33, $7 \&$ n.34.

3. Phillips v. United States, 312 U.S. 246, 250 (1941).

4. 28 U.S.C. $\$ 2281$ (1970). For the text of this section, see p. 568 infra.

In 1937 Congress extended the three judge-direct review procedure to constitutional challenges to federal statutes. 28 U.S.C. $\$ 2282$ (1970).

5. 28 U.S.C. $\$ 1253(1970)$ :

[A]ny party may appeal to the Supreme Court from an order granting or denying

... an interlocutory or permanent injunction in any civil action... required

by any Act of Congress to be heard and determined by a district court of three

judges.

6. See 45 CoNG. REC. 7253 (1910) (remarks of Sen. Burton). The Supreme Court has stated that assuring careful deliberation is an important purpose of the Act. Phillips $v$. United States, 312 U.S. 246, 250 (1941); Cumberland Tel. \& Tel. Co. v. Louisiana Pub. Serv. Comm'n, 260 U.S. 212, 216 (1922).

7. See Currie, supra note 1 , at $7 \&$ n.42, 8. Another rationale for the Act was a desire to quiet public discontent with unpopular decisions: "If three judges declare that a statute is unconstitutional the people would rest easy under it." 45 Cong. REC. 7256 (1910) (remarks of Sen. Overman). See Note, The Three-Judge Court Reassessed, 72 YALE L.J. 1646, 1652-53 (1963). 
Act applied only to preliminary injunctions, by which a single district judge, often after an ex parte hearing, could forestall the operation of important state legislation for lengthy periods before resolution of the merits. ${ }^{8}$ With little explanation, Congress subsequently extended the Act to applications for permanent injunctions. ${ }^{9}$ As amended, it is now codified at 28 U.S.C. $\$ \$ 1253,2281$ and 2284.

The Three-Judge Court Act has proven onerous. ${ }^{10}$ Empanelling three judges disrupts the dockets of both district and circuit courts, ${ }^{11}$ especially since three-judge cases take precedence over all others. ${ }^{12}$ The complexity of the Act leads to confusing searches for the proper forum, delay, a waste of judicial resources, and added expense for litigants. ${ }^{13}$ Moreover, the right of direct review burdens the Supreme Court with a growing compulsory docket at a time when its caseload al-

8. See Hutcheson, A Case for Three Judges, 47 Harv. L. REv. 795, 800-04 (1934). For an argument that the particular evils of the ex parte interlocutory injunction that gave rise to the Three-Judge Court Act have been eliminated, obviating the need for the Act, see Comment, The Three-Judge Federal Court in Constitutional Litigation: $A$ Procedural Anachronism, 27 U. CHI. L. REv. 555, 558.59 (1960). The Comment also argues that federal-state tensions have subsided. But see Note, The Three-Judge District Court and Appellate Review, 49 VA. L. REv. 538, 569 (1963), concluding that federalstate relations are still "sufficiently delicate" to justify the three-judge court procedure and citing as an example the friction caused by the reapportionment cases.

9. In 1925 Congress amended the Act to include applications for permanent injunctions, Act of Feb. 13, 1925, ch. $229, \S 1,43$ Stat. 938, in order to eliminate the "anomaly" of a single judge deciding the application for the permanent injunction after three judges had decided the interlocutory request. Ex parte Buder, 271 U.S. 461,465 (1926); 66 Cong. Rec. 291 (1924) (remarks of Sen. Cummins). The Supreme Court construcd the amendment to extend to permanent injunctions only when the plaintiff also had applied for an interlocutory injunction. Smith v. Wilson, 273 U.S. 388 (1927). In the 1948 revision of the Judicial Code, the Act was extended to any application for a permanent injunction, whether or not an interlocutory injunction had been requested. Act of June 25, 1948, ch. 646, $\$ 2281,62$ Stat. 996 (codified in 28 U.S.C. $\$ 2281$ (1970)).

10. From 1964 to 1973 , the number of cases for which three-judge courts were convened increased from 119 to 320 . Over 15 percent of those cases, however, were revirws of ICC orders under a statute now repealed. 28 U.S.C. $\$ \S 2324,2325$ (1970), repealed by Act of Jan. 2, 1975, Pub. L. No. 93-584, 88 Stat. 1917. Moreover, the rate of annual increase of three-judge cases has slowed since 1971. See ANNuAL Report, AdMinistritive OfFice of the U.S. CourTs 151 (1973) (table).

11. See Phillips v. United States, 312 U.S. 246, 250-51 (1941); H.R. REP. No. 93-1569, 93d Cong., Ist Sess. 5 (1974) (comments of Chief Judge Harry Phillips, Sixth Circuit, and Judge J. Skelly Wright, D.C. Circuit); Ammerman, Three-Judge Courts: See How They Run!, 52 F.R.D. 293, 293-94, 304-06 (1971).

12. 28 U.S.C. $\$ 2284(4)(1970)$.

13. "Unhappily, the [three-judge court] scheme is far from simple in its operation." 9 Moore's Federal Practice f 110.03[3], at 69 (2d ed. 1975). For an analysis of the "bewildering problems" in the area of appellate review, see id. at 70-85. The rules governing appellate review of decisions on whether a special court is required are "so complex as to be virtually beyond belief." AMERICAN LAw INSTITUTE, STUdy OF THE Division of the JuRisdiction BetweEN State and Federal Courts 332 (1969) [hereinafter cited as ALI STunY]. The three-judge court procedures so perplexed one "helpless litigant" that he traveled to eight separate forums in his search for relief. S. REP. No. 94-204, 94th Cong., Ist Sess. 7 (1975). 
ready strains its capacity. ${ }^{14}$ The Court increasingly disposes of these three-judge cases in summary proceedings, without argument or written opinion. ${ }^{15}$ Hence many three-judge court decisions do not receive full review by any higher court. In response to arguments that the three-judge court statutes are unduly burdensome and confusing, the Senate twice has passed a bill that eliminates the three-judge court and direct review procedures for most constitutional challenges to state and federal legislation. ${ }^{16}$ The House of Representatives currently is considering a similar bill. ${ }^{17}$

This Note proposes a construction of the provisions of the Judicial Code relating to three-judge courts and declaratory judgments ${ }^{18}$ which would greatly reduce the need for congressional action by alleviating many of the present difficulties of the three-judge court requirement. The proposed construction builds on the evolving interpretation of the Three-Judge Court Act and reflects the full import of the Declaratory Judgment Act of 1934.19

\section{The Use of the Declaratory Judgment to Curtail the Need for Three-Judge Courts}

The Three-Judge Court Act neither compels nor encourages the grant of injunctions. On the contrary, the cumbersome procedure set up by the Act evinces congressional wariness of the power to enjoin

14. See Symposium, The Freund Report: A Statistical Analysis and Critique, 27 Rur. L. REv. 878, 897-99, 902 (1974); RLPORT of THE Study Group ON THE CASELOAd OF the SuPREME CourT 30 (1972); Burger, The State of the Federal Judiciary-1972, 58 A.B.A.J. 1049, 1053 (1972); W. Burger, Annual Report on the State of the Judiciary (Feb. 16. 1976), reprinted in $96 \mathrm{~S}$. Ct. 4,5 (1976) (front pages). See generally Hart, Foreword: Thc Time chart of the Justices, 73 HARv. L. REv. 84 (1959).

15. See Gonzalez v. Automatic Employees Credit Union, 419 U.S. 90, 99 n.li (1974) (nearly three-fourths of the appeals from three-judge courts are disposed of in summary proceedings).

16. On September 25,1975 , the Senate passed S. 537, 94th Cong., 1st Sess. $\$ \$ 1-3$ (1975), which preserves the three-judge court "when otherwise required by Act of Congress or when an action is filed challenging the constitutionality of the apportionment of congressional districts or the apportionment of any statewide legislative body." $\$$. $537 \$ 3$. See S. REp. No. 94-204, 94th Cong., 1st Sess. 2-5 (1975) (purpose of S. 537 is to reduce burden on the federal judiciary and to eliminate confusion for litigants).

17. The House bill, H.R. 6150, 94th Cong., 1st Sess. $\$ \$ 1,2$ (1975), preserves three. judge courts for apportionment cases, as does the Senate bill, but it also requires the special panel to convene for actions challenging the enforcement of state or federal statutes when "such action is based on specific allegations that such statute . . . is unconstitutional in that it discriminates against the plaintiff because of his race." Id. $\$ 2$.

18. 28 U.S.C. $\$ \$ 2201,2202$ (1970). Section 2202 provides: "[A]ny court of the Unitcd States . . may declare the rights and other legal relations of any interested party seeking such declaration ...."The declaratory judgment differs from an injunction in that it is not accompanied by the threat of a contempt sanction. See $O$. Fiss, INJunctions 51 (1972) (injunction is "a declaratory judgment plus a coercive order").

19. 28 U.S.C. $\$ \$ 2201,2202(1970)$. 
the enforcement of state statutes. Twenty-four years after it passed the Three-Judge Court Act, Congress enacted the Declaratory Judgment Act to create an alternative to the injunction. As a simple declaration of rights unaccompanied by an immediate threat of contempt, the declaratory judgment is milder than the injunction and is therefore better suited to the invalidation of unconstitutional state statutes by federal courts. ${ }^{20}$ Because the declaratory judgment will often be a fully adequate remedy, the Declaratory Judgment and Three-Judge Court Acts together should be construed as urging federal courts to dismiss an application for a permanent injunction without reaching the constitutional grounds on which the state statute is challenged, and to consider instead whether a declaratory judgment should be granted. Such a disposition, if within the power of a single district judge, would curtail sharply the need for three-judge courts. The special procedures set forth in the Three-Judge Court Act would be needed only in considering requests for preliminary injunctions, the cases to which the Act originally applied. ${ }^{21}$

Pending issuance of a declaratory judgment, the federal courts must continue to consider requests for preliminary injunctions. In this situation, the requirement of a three-judge court comports more fully with the statutory purpose; the danger of bias and poor judgmentthe threat of "improvident doom" to state legislation-is more severe, because a request for preliminary relief must be decided before a full hearing on the merits.

This proposal would eliminate the need for a three-judge court in any action in which a preliminary injunction is not requested. Where a preliminary injunction is requested, the procedures suggested here still would reduce substantially the drain on judicial resources. Suppose, for example, a plaintiff challenges a state statute on constitutional grounds, asking for preliminary and permanent injunctions and a declaratory judgment. ${ }^{22}$ The application for a preliminary injunction triggers the three-judge court requirement-a district judge and a circuit judge join the one to whom the application was made. Sitting

20. See pp. 578-81 infra.

21. Fourteen years after the enactment of the Declaratory Judgment Act, Congress extended the Three-Judge Court Act to cover the isstuance of permanent injunctions. See note 9 supra. This amendment reflected a congressional recognition that federal courts were continuing to grant permanent injunctions against unconstitutional state statutes despite the availability of the declaratory judgment as an alternative remedy. But congressional recognition of this practice can in no way be considered an endorsement of it. To the contrary, by requiring the safeguards of the Three-Judge Court Act, Congress indicated its reservations about the use of the permanent injunction to invalidate state legislation.

22. When the plaintiff seeks permanent injunctive relief but not a declaratory judgment, the district court should dismiss with leave to file an amended complaint requesting declaratory relief. See FED. R. Civ. P. 15(a). 
together, they determine whether or not to grant preliminary relief; their determination can be appealed directly to the Supreme Court. To this extent, current practice is unchanged.

What is changed, however, is the practice of reconvening the threejudge court to rule on the request for permanent relief after it has disposed of the request for preliminary relief. Under the proposal of this Note, the single judge would dismiss the request for a permanent injunction and proceed to decide whether a declaratory judgment should be granted, with appeal from that decision to the court of appeals. As a result, two of the three judges would not have to participate in the full trial on the merits. ${ }^{23}$

Part II of this Note addresses the question whether the ThreeJudge Court Act deprives the single judge of the power to follow these procedures. After concluding that the single judge has that power, the Note argues in Part III that the procedures are fully consistent with the principles of equity and comity which govern constitutional challenges to state statutes in the federal courts.

\section{Jurisdictional Limitations on the Single Judge: Issue Divisibility}

The Supreme Court long has construed the Three-Judge Court Act to transfer to the specially-constituted court a broader jurisdiction than the Act actually conveys. On its face, $\$ 2281$ of the Judicial Code does no more than redistribute the power to grant injunctions on constitutional grounds:

[An] injunction restraining the enforcement . . of any state statute... shall not be granted ... upon the ground of the unconstitutionality of such statute unless ... heard and determined by a district court of three judges ....

Reading the language of the statute literally, a single judge would have power to hear and deny an application for an injunction on constitutional grounds. Yet early cases imported the word "denied" into $\$ 2281$, presumably to avoid the possibility that a three-judge court would have to reconsider the merits whenever a single judge decided not to deny the injunction. ${ }^{24}$ Initially, the Supreme Court

23. A three-judge court convened to hear an application for a preliminary injunction may advance the trial on the merits and consolidate it with the hearing on prcliminary relief, thus allowing the court to dispose of the requests for a permanent injunction and a declaratory judgment. See FED. R. Civ. P. 65(a)(2). However, the three-judge court is unlikely to advance and consolidate if the trial on the merits would impose a substantial burden on it.

24. Ex parte Metropolitan Water Co., 220 U.S. 539 (1911). See Currie, supra note 1, at $20-21$. 
construed the Act even more broadly to transfer jurisdiction over the whole case whenever the plaintiff requested an injunction against a state statute. ${ }^{25}$

The burden on the federal judiciary imposed by the Act, however, led the Court slowly to narrow its construction. ${ }^{26}$ In recent years the enormous increase in the caseload of federal courts has reinforced the desire to reduce this burden. ${ }^{27}$ Analysis of recent cases interpreting the $\mathrm{Act}^{28}$ shows that requests for injunctive and declaratory relief on the same constitutional grounds can be divided between single-judge and three-judge courts, allorving the single judge to grant declaratory relief without convening a three-judge court. ${ }^{29}$

25. See, e.g., Ex parte Madden Bros., 283 U.S. 807 (1931) (mandamus granted to compel formation of three-judge court where single judge had dismissed for want of jurisdiction). Not until Ex parte Poresky, 290 U.S. 30, 31-32 (1933), was it clearly established that a single judge even had the power to dismiss for want of jurisdiction. Note, 28 MIIN. L. REv. 131 \& n.4 (1943) ("on principle" it would seen that prior to 1933 a single judge could not dismiss for lack of jurisdiction).

26. See, e.g., Swift \& Co. v. Wickham, 382 U.S. 111, 128-29 (1965) (overruling Kesler v. Dep't of Pub. Safety, 369 U.S. 153 (1962)); Phillips v. United States, 312 U.S. 246, 250-51 (1911) (Congress was "mindful that the requirement of three judges . . . entails a serious drain upon the federal judicial system"; $\$ 2281$ is not "a measure of broad social policy to be construed with great liberality, but ... an enactment technical in the strict sense of the term and to be applied as such.") The Court justified its narrow construction of $\$ 2281$ by its duty to honor a countervailing purpose of Congress to "keep within narrow confines our appellate docket," expressed in the Judiciary Act of 1925. Id. at 250. For discussion of the purpose of the $1925 \mathrm{Act}$, sec Taft, The Jurisdiction of the Supreme Court Under the Act of Feb. 13, 1925, 35 Yale L.J. I (1925); F. Frankfurter \&: J. Landis, The Business of the Supreme Court 119, 25j-94 (1928).

27. Report of the Study Group on the Caseload of THE Supreme Court 9, 25-30 (1972); W. Burger, Annual Report on the State of the Judiciary (Feb. 16, 1976), reprinted in 96 S. Ct. 4, 5 (1976) (front pages).

28. While this Note focuses on $\S 228 \mathrm{I}$, it draws upon cascs construing $\S 2282$, which requires the three judge-direct review procedure for constitutional challenges to acts of Congress. Section 2282 was modeled on $\$ 2281$, and the direct review provision of both sections is incorporated in $\$ 1253$. Their policies are parallel: $\$ 2282$ was designed to mitigate tensions between two branches of the federal government, and $\$ 2281$ to mitigate tensions between federal and state governments. While today friction between federal and state governments is more serious than that between the legislative and judicial branches of the federal government, see ALI STUDY, supra note 13 , at 325 , courts generally apply the same standards under the two sections for requiring three judges or permitting direct review. See Kennedy v. Mendoza-Martinez, 372 U.S. 144, 154 (1963) (relying on a $\$ 2281$ case for a $\$ 2282$ holding); Gunn v. University Comm. to End the War in Vietnam, 399 U.S. 383, 387 (1970) (relying on $\$ 2281$ and $\$ 2282$ cases in dismissing an appeal from a decision under $\$ 2281$ ). The construction proposed here for $\$ 2281$ is thus appropriate for $\$ 2282$. Furthermore, the declaratory judgment is a preferred remedy for invalidating federal as well as state statutes. Cf. pp. 578-81 infra.

29. When only declaratory relief is requested, a three-judge court is not required, since a declaratory judgment is not an "injunction" within the meaning of the threejudge court statutes. See Mitchell v. Donovan, 398 U.S. 427,430 (1970) ("While there are similarities between injunctions and declaratory judgments, there are also important differences."); Kennedy v. Mendoza-Martinez, 372 U.S. 144, 154 (1963) (construing $\$ 2282$ ). But see Currie, supra note 1 , at $14-20$ (arguing that a declaratory judgment should be considered an injunction within the meaning of the three-judge court statutes); Developments in the Law-Declaratory Judgments, 65 HARv. L. Rev. 787, 869-70 
In limiting the jurisdiction of three-judge courts, the Court began by narrowly defining the class of cases to which the Act applies. For example, the Court has held that the Act does not apply when the statute is challenged under a state constitution. ${ }^{30}$ Nor does it apply when the plaintiff challenges the constitutionality of a municipal ordinance, ${ }^{31}$ or of a state statute having only local effect. ${ }^{32}$ Similarly, a state law alleged to be in conflict with a federal law and challenged under the supremacy clause need not be reviewed by a three-judge panel, since the interpretation of the statutes, not the Constitution, is the basic issue in the case.

In addition to narrowing the class of cases over which the threejudge court has jurisdiction, the Court has divided cases into "singlejudge" and "three-judge" issues, and has progressively reduced the latter category. ${ }^{34}$ This division avoids the need for a three-judge court when resolution of a "single-judge" issue disposes of the case. Even if the resolution of that issue is not dispositive, the work of the special court is reduced..$^{35}$

(1949). Testifying in favor of the creation of a federal declaratory judgment remedy, Professor Edwin Borchard proposed that the bill be amended to require a threc-judge court for a declaratory judgment as well as for an injunction against a statc statute. Professor Edson Sunderland argued that a three-judge court should not be requircd to grant a declaratory judgment. Hearings on H.R. 5623 Before a Subcomm. of the Senatc Comm. on Judiciary, 70th Cong., 1st Sess. 38-39 (1928). The amendment suggested by Borchard was not incorporated in the Declaratory Judgment Act, as subsequently cn* acted by Congress in 1934 .

30. Ex parte Buder, 271 U.S. 461, 465 (1926); Ex parte Williams, 277 U.S. 267, 271 (1928).

31. Moody v. Flowers, 387 U.S. 97, 101 (196i).

32. Id.; Ex parte Collins, 277 U.S. 565, 567-68 (1928). See HART AND WechsLer, supra note 1 , at $970-72$.

33. Swift \& Co. v. Wickham, 382 U.S. 111, 120-21, 128 (1965) ("The basic question involved in these cases, however, is never one of interpretation of the Constitution but inevitably one of comparing two statutes.")

34. Although in 1942 Congress limited the powers of a single judge, 28 U.S.C. $\$ 2284(5)$ (1970), the Court has found those limitations to apply only after three judges properly have been convened. Idlewild Bon Voyage Liquor Corp. v. Epstein, 370 U.S. 713, 715 (1962).

35. A single judge has no power to decide a three-judge issue, but a three-judge court may decide single-judge issues. See Hagans v. Lavine, 415 U.S. 528, 543-44 (1974) (\$2281 permits but does not require statutory claim to be heard by single judge); Swift \& Co. v. Wickham, 230 F. Supp. 398,410 n.10 (S.D.N.Y. 1964), appeal dismissed, 382 U.S. 111 (1965) (discussing possible rationales for allowing an improperly convened threejudge court to act as a single judge); 9 MoOre's Frofral Practice $f$ 110.03[3], at 80 n.50 (2d ed. 1975) ("The implication would seem to be that if the three-judge court considers the nonconstitutional claim and grants injunctive relief on the basis of it, it is simply doing the work of a single judge. . . ., discussing Rosado v. Wyman, 397 U.S. $397(1970))$.

The three-judge court has no authority to review single-judge issues already decided except to determine whether the special panel has been properly convened. It is not a "truncated court of appeals." Doe v. Lukhard, 493 F.2d 54, 59 (4th Cir. 1974), vacated on other grounds, 420 U.S. 999 (1975). See Parks v. Harden, 504 F.2d 861, 866 (5th Cir. 1974), vacated on other grounds, 421 U.S. 926 (1975); Murrow v. Clifford, 502 F.2d 1066, 1069 (3d Cir. 1974). 
The first step was to allow a single judge to decide only preliminary issues such as justiciability or the existence of a substantial federal question. ${ }^{36}$ The three-judge court retained responsibility for the merits of the case. That responsibility formerly extended to statutory claims joined with a constitutional claim, ${ }^{37}$ but recently the Court has allowed division of the merits between single-judge and threejudge courts. ${ }^{38}$

In Hagans $v$. Lavine, ${ }^{39}$ the plaintiff challenged the constitutionality of a New York welfare regulation. A single judge avoided a substantial constitutional claim, enjoining enforcement of the regulation on the basis of an accompanying statutory claim. ${ }^{40}$ On review, the Supreme Court approved, stating that the single judge's action "accurately reflects ... this Court's concern for the efficient operation of the lower federal courts." +1 Hagans holds that a single judge can decide a statutory claim joined with a constitutional claim without convening a three-judge court. ${ }^{42}$ The Court thus recognized that the Three-Judge Court Act transferred only a narrow segment of the power of the single judge to the special panel.

36. Ex parte Poresky, 290 U.S. 30, 31-32 (1933) (single judge may dismiss an action for want of a substantial federal question); Gonzalez v. Automatic Employees Credit Union, 419 U.S. 90, 100 (1974) (justiciability a single-judge issue, citing Poresky).

37. Florida Lime \& Avocado Growers, Inc. v. Jacobsen, 362 U.S. 73 (1960) (state statute challenged under equal protection and commerce clauses of the Constitution and under the Federal Agricultural Marketing Agreement Act of 1937). Both the majority and the dissent assumed that statutory and constitutional claims could not be divided between two courts. The majority held that the three-judge court must decide all claims. The dissenters argued that the single judge first should consider the statutory claim in order to avoid the constitutional claim; if his resolution was not dispositive, the single judge would have to proceed to the constitutional claim. Id. at 84-85, 91 .

38. Hagans v. Lavine, 415 U.S. 528, 543-45 (1974). See Rosado v. Wyman, 397 U.S. 397, 403 (1970) ("[T]he most appropriate course may well have been [for the three-judge court] to remand to the single district judge for findings and the determination of the statutory claim [accompanying a constitutional claim].") (dictum).

39. 415 U.S. 528 (1974).

40. Id. at $532-33$.

41. Id. at 544, citing Swift \&. Co. v. Wickham, 382 U.S. 111 (1965).

42. In Murrow v. Clifford, 502 F.2d 1066, 1067-68 (3d Cir. 1974), a divided panel held that a single judge cannot deny a statutory claim, and distinguished Hagans on the ground that the single judge there had granted the statutory claim. The Murrow court considered it improper for the single judge, by denying the statutory claims, to deprive the three-judge court of the opportunity to avoid the constitutional issue. But in Hagans, 415 U.S. at 544-45, the Supreme Court had cited Norton v. Richardson, 352 F. Supp. 596, 598.99 (D. Md. 1972), which rejected the position of the Murrow majority. For criticism of Murrow, see 88 HaRv. L. REv. 1028 (1975); Note, Suits to Enjoin State Statutes On Constilutional And Federal Preemption Grounds: Allocation of Jurisdiction Between The Single District Judge And The Three-Judge Court, 64 GEo. L.J. 113, 118-22 (1975). For evidence that the Hagans procedure of dividing statutory and constitutional issues between single-judge and three-judge courts may impose a greater burden on both judiciary and litigants than leaving both issues to the three-judge court, see id. at 120-22. For problems of appeal posed by the Hagans division, see id. at 123-26; 88 HARv. L. Rev. 1028, 1030-31 (1975). 
MTM, Inc. v. Baxley ${ }^{43}$ further reduced the category of three-judge issues. Under Alabama nuisance law, a state court preliminarily enjoined the operation of plaintiff's Pussycat Adult Theater. With the action for a permanent injunction pending in a state court, the plaintiff sued in federal court to enjoin enforcement of the preliminary injunction, challenging the constitutionality of the statute. A threejudge court dismissed the complaint without resolving the constitutional merits, on the ground that the pending proceedings made federal intervention inappropriate. ${ }^{* 4}$ The plaintiff appealed directly to the Supreme Court under $\$ 1253$. The Court denied review, holding that the three-judge court's dismissal did not constitute a denial of injunctive relief within the meaning of that section. It construed $\S 1253$ to provide direct appeal from a denial of injunctive relief only where the denial "rests upon the resolution of the merits of the constitutional claim presented below," and concluded that a dismissal on the ground of impropriety of federal intervention was not such a denial. ${ }^{45}$

The MTM Court refused to decide whether a single judge had the power to dismiss on this ground.46 However, to deny direct review of such a decision and still to require the decision to be made by a three-judge court would, as Justice White asserted in his concurrence, "manhandl[e] the language" of $\S 1253 .{ }^{47}$ That section allows an appeal to the Supreme Court from "any order granting or denying" an injunction in any civil action "required ... to be determined by ... three judges." If no direct appeal lies from an order in an action required to be heard by three judges, the disposition must not have been "an order granting or denying" an injunction. But $\$ 2281$ requires three judges only for injunctions "granted" by any district court. Hence the possibility left open by the $M T M$ Court could arise only if, in an Act originally passed as one section," the "grant" of an injunction (under $\$ 2281$ ) were somehow construed to reach a broader range of denials than the "grant or denial" of an injunction (under $\S 1253$ ). ${ }^{49}$ Moreover, as Justice White pointed out, to require

43. 420 U.S. 799 (1975).

44. Id. at 800 .

45. Id. at 804 .

46. Id. at 802 n.7.

47. Id. at 805 .

48. The Three-Judge Court Act was enacted as one section ( $\$ 17$ ) of the Act of June 18, 1910, ch. 309 , 36 Stat. 539 .

49. The Court has construed $\$ 2281$ to require three judges to deny as well as to grant injunctions on the ground of unconstitutionality. See pp. $568-69$ supra. Accepting the established rule that both sections apply to orders granting or denying injunctions, construing the implied "denial" of $\$ 2281$ more broadly than the express "denial" of $\S 1253$ still is not justified. In deciding whether to permit a direct appeal, the Supreme 
both a decision by three judges in the district court and an appeal to another panel of three judges in the court of appeals would be "an exorbitant waste of judicial manpower." so

Thus, if $\S 1253$ is construed to prevent direct review of a decision that an injunction against enforcement of a state statute would be inappropriate, $\S 2281$ should be construed to permit a single judge to make that disposition." ${ }^{51}$ After $M T M$, the only issues left for decision by the three-judge court should be the constitutional merits. ${ }^{.2}$

The Court stretched the concept of issue divisibility to the limit in Steffel $\%$. Thompson. ${ }^{53}$ State officers had threatened to charge the plaintiff with criminal trespass if he continued to distribute antiwar handbills in a shopping center. A single judge denied both declaratory and injunctive relief in the ensuing constitutional challenge

Court long has implicitly equated \$2281's "grant" and \$ 1253's "granting or denying" by focusing on $\$ 1253$ 's requirement that the injunction be granted or denied in an action "required by an Act of Congress to be determined by . . . three judges." Gonzalez v. Automatic Employees Credit Union, 419 U.S. 90, 95 n.12, 96 n.14 (1974). But see Philbrook v. Glodgett, 421 U.S. 707, 712 n.8 (1975) (decision of three-judge court on statutory grounds was appealable directly to the Supreme Court, even though single judge could have resolved the statutory claim, which was not raised until oral argument before three-judge court).

50. 420 U.S. at 806 .

51. MTM undermines the authority of Idlewild Liquor Corp. v. Epstein, 370 U.S. 713 (1962), which held that $\$ 2281$ requires three judges for a decision to abstain "in order to give the state courts an opportunity to pass upon the constitutional issues presented. . . Concurring in $M T M$, Justice White urged that Idlewild be overruled: "[c]ases like Idlcwild are derelicts and should be expressly cleared from the scene." 420 U.S. at 807 (footnote omitted). In explicitly avoiding the implications of its decision for $\$ 2281$, the Court did not mention Idlewild, cren though Justice White's concurrence and Justice Douglas's dissent questioned its continuing authority. Id. at $802 \mathrm{n} .7,805-06$ \&.1, 809 .

In a recent decision the Sccond Circuit ostensibly respected the Idlewild rule that abstention requires three judges, but it seemed to recognize the post-MTM weakness of that authority. McRedmond v. Wilson, No. 75-7389, slip op. at 1752 (2d Cir., Feb. 2, 1976). The court circumvented Idleu'ild by attributing to the single judge, who had abstained, a sub silentio ruling that the constitutional question was insubstantial. Without the sub silentio attribution, Idlewild would have required the coturt of appeals to find the single judge's decision void for want of jurisdiction.

52. The three-judge court in $M T M$ dismissed the request for an injunction against pending state criminal proceedings under the rule of Younger v. Harris, 401 U.S. 37 (1971). 420 U.S. at $801-02$. The procedure suggested in this Note-that the single judge dismiss requests for permanent injunctions in favor of declaratory judgments-is rooted in the same underlying principles as the Younger rule. See pp. 576-77 \& nn.68-69 infra.

Since MTM implies that the single judge may dismiss under Younger; a fortiori he may dismiss under the proposed rule. Before $M T M$ the rationale for requiring three judges for a Younger dismissal had been that "an exercise of discretion will usually be necessary." Steffel v. Thompson, 415 U.S. 452, 457 n.7 (1974) (Brennan, J.). But see Colorado River Water Conservation Dist. v. United States, 44 U.S.L.W. 4372, 4376 n.22 (U.S. Mar. 23, 1976) ("no discretion to grant injunctive relief" where case is properly within Younger) (Brennan, J.). Under the rule proposed here, the district judge would, as a matter of course, dismiss the request for a permanent injunction; an exercise of discretion would be unnecessary.

53. 415 U.S. 452 (1974). 
of the trespass statute; the Fifth Circuit affirmed the denial of declaratory relief. ${ }^{54}$

The Supreme Court stated that a three-judge court should have been convened below. ${ }^{5 \overline{5}}$ If indeed a three-judge court were required, the single judge would have lacked power to decide the case, and his decision would have been void for want of subject matter jurisdiction; the court of appeals also would have lacked jurisdiction and would have had to remand for the convening of a three-judge court. ${ }^{56}$ Yet the Supreme Court upheld the jurisdiction of the court of appealsand thus necessarily that of the district court..57

The Court's assertion that a three-judge court should have been convened cannot be reconciled with its disposition of the case unless a single judge has power to grant or deny a declaratory judgment even when the plaintiff also requests injunctive relief on the same constitutional grounds. ${ }^{58}$ The Supreme Court could have found jurisdiction below only by interpreting $\S 228 \mathrm{I}$ as dividing the power to decide requests for declaratory and injunctive relief between singlejudge and three-judge courts. Steffel necessarily implies that the ThreeJudge Court Act transfers nothing more than the power to grant or deny the injunctive remedy in a constitutional challenge to a state statute. The single judge always retains the power to grant a declaratory judgment.59

54. Id. at 456-57. Petitioner appealed the denial of both injunctive and declaratory relief. However, the Court found that he "abandoned" the appeal from the denial of the injunction in his brief in the court of appeals. $I d$. at $456 \mathrm{n} .6$.

55. Id. at 457 n.7: "Since the complaint had originally sought to enjoin enforcement of the state statute on grounds of unconstitutionality, a three-judge district court should have been convened."

56. See Kennedy v. Mendoza-Martinez, 372 U.S. 144, 152-55 (1963) (construing $\$ 2282$ ) (dictum); Idlewild Liquor Corp. v. Epstein, 370 U.S. 713, 716 (1962); Borden Co. v. Lilly, 309 F.2d 871 (8th Cir. 1962), cert. denied, 372 U.S. 953 (1963) (the court af appeals first raised the question of jurisdiction and found that it had to remand for trial before a three-judge court); Currie, supra note 1 , at $\mathrm{pp.76-77.}$

57. 415 U.S. at 457 n.7: “But since petitioner's request for injunctive relief was abandoned on appeal . . . and only a request for declaratory relief remained, the Court of Appeals did not err in exercising jurisdiction over the appeal." The Court went on to hold that the district court and the court of appeals erred in denying went on to hold that the district court and the court of appeals erred in relying on the same considerations to deny declaratory relief as they did to deny injunctive relicf.

58. To support its finding of jurisdiction, the Court cited four cases in which a three-judge court had made the disposition below. Id. These cases were utterly inapposite to Steffel, in which the Court was reviewing the decision rendered by a single judge.

59. The district court in Steffel denied declaratory relief as inappropriate under Younger v. Harris, 401 U.S. 37 (1971). Becker v. Thompson, 334 F. Supp. 1386 (N.D. Ga. 1971), rev'd sub nom., Steffel v. Thompson, 415 U.S. 452 (1974). Hence neither the court of appeals nor the Supreme Court reached the underlying question of the constitutionality of the state criminal statute. The narrowest interpretation of the Court's holding in Steffel is simply that a single judge has power to deny declaratory relief on Younger grounds. But a logical implication of that holding is that a single judge has power to reach the underlying constitutional merits in order to grant or deny a declaratory judg- 
The Second Circuit recently embraced the logic of Steffel in Stone v. Philbrook..$^{00}$ Plaintiff asked for declaratory and permanent injunctive relief against enforcement of a Vermont welfare regulation. ${ }^{61} \mathrm{~A}$ single judge granted declaratory relief, but ignored the request for the injunction. ${ }^{62}$ On appeal, the state challenged the jurisdiction of the single judge and hence of the court of appeals. ${ }^{63}$ Relying on Steffel, the court of appeals found jurisdiction:

[I]t would seem to follow a fortiori [from Steffel] that the court of appeals has jurisdiction when a single judge has only taken action he could properly take, even though he was asked to take action he could not properly take and made no disposition of the request to do more. ${ }^{64}$

Philbrook thus held that the single judge has power to grant declaratory relief when he fails to act on an additional claim for an injunction based on the same constitutional ground.

Writing for the panel, Judge Friendly expressed dismay at the "new puzzlement" created by Steffel and MTM in the "never-never land" of three-judge courts. ${ }^{65}$ Yet as analyzed here these cases dispel

ment since, when the Court decided Steffel, a dismissal under Younger was considered a denial on the merits for purposes of $\$ 2281$. "A three-judge court . . . is normally required even if the decision is to dismiss under Younger-Samuels principles . . . ." 415 U.S. at 457 n.7. (The Court's decision a year later in MTM, Inc. v. Baxley, 420 U.S. 799 (1975), may be read to authorize a single judge to dismiss under Younger. See p. 572 supra).

60. 528 F.2d 1084 (2d Cir. 1975).

61. In his complaint, Stone asked for a declaratory judgment, a temporary restraining order, a preliminary injunction, and a permanent injunction. The temporary restraining order had been granted before Stone moved for summary judgment. Id. at 1086. Since Stone had already obtained preliminary relief, only the requests for a permanent injunction and a declaratory judgment were before the court in the hearing on his motion for summary judgment.

The court should have convened a three-judge court to review the grant of the temporary restraining order. 28 U.S.C. $\$ 2284(3)$. However, that order was not before the court of appeals.

62. 528 F.2d at $1089-90$ (district court failed to act on the request for an injunction); see id. at 1087-88 (court of appeals quotes district court's grant of plaintiff's motion for summary judgment, declaring state policy unconstitutional but making no disposition of the request for injunctive relief).

63. Id. at 1088-89. After the entry of the district court's declaratory order, the defendant moved to vacate the order for lack of jurisdiction, alleging that a three-judge court should have been convened under $\$ 2281$. Id. at 1088 . On appeal, the defendant asked the court to reverse and remand for the convening of three judges.

64. Id. at 1089 (emphasis added). After finding that it had jurisdiction to review the decision of the single judge, the circuit court went on to reach the merits of the grant of declaratory relief. It vacated the judgment of the district court and remanded with specific instructions that the single judge retain jurisdiction pending resolution of a state law question in the Vermont courts. Id. at 1094.

65. Judge Friendly started from the premise that "if either party had requested the convening of a three-judge court, the request should have been granted." Id. at 1088 . He hinted that his finding of jurisdiction, which he realized was compelled by Steffel, 
much of the confusion surrounding the Three-Judge Court Act by restricting its reach to the grant or denial of injunctive relief on the constitutional merits. When a single judge is confronted with claims for declaratory and injunctive relief against a state statute, Steffel implies that he has jurisdiction to grant the declaratory judgment; $M T M$ implies that he can dismiss the request for the injunction so long as he does not reach the constitutional merits.

The single judge in Philbrook therefore had the power to decide the request for a declaratory judgment while failing to grant the request for a permanent injunction. ${ }^{66}$ Part III of this Note argues that the single judge should exercise that power and forthrightly dismiss a request for a permanent injunction in light of fundamental principles of equity and federalism. ${ }^{67}$

\section{The Declaratory Judgment as a Preferred Remedy}

A basic principle of equity jurisprudence holds that a court should not grant an injunction where the petitioner is not threatened with irreparable harm. That doctrine assumes special importance in the context of federal-state relations, because of the danger that an injunction will "unduly interfere with the legitimate activities of the

could be explained on a theory that the state had waived the right to a thrce-judge court by "belatedly" requesting it after the single judge had granted summary judgment for the plaintiff. Id. at 1088, 1090. This waiver theory, however, ignores the jurisdictional nature of $\$ 2281$. That section redistributes judicial pouter; where a single judge lacks power to decide an issue, he must convene a three-judge court, whether or not a litigant requests it. See Kennedy v. Mendoza-Martinez, 372 U.S. I44, 153 (1963) (decided under $\$ 2282$ ); Stratton v. St. Louis S.W. Ry., 282 U.S. 10, 18 (1930); Ex parte Metropolitan Water Co., 220 U.S. 539, 542-43 (1911); ALI STUdY, supra note 13, at 331; Curric, supra note 1, at 76-77; Currie, Appellate Review of the Decision Whether or Not to Empanel a Three-Judge Federal Court, 37 U. CHI. L. REv. 159, 159 (1969); Note, supra note 42, at 114 n.3 (1975).

66. Although not before the court of appeals in Philbrook, 528 F.2d at 1089.90, the failure of the district judge to act on the request for an injunction was clearly improper. This Note proposes that, rather than simply ignore such a request, a single judge should dismiss it on the ground that federal injunctive relief is inappropriate.

67. The only other alternative to the traditional practice of treating requests for declaratory and injunctive relief as indivisible is to allow the plaintiff to seek the two forms of relief in separate courts. For judicial discussion of such an attempt, see Spencer v. Kugler, 454 F.2d 839, 840 (3d Cir. 1972); id. at 847:

[I] $\mathrm{t}$ is theoretically possible for a challenge to the constitutionality of state statutes to proceed simultaneously along two routes at the district court level-before a single judge by way of a request for declaratory relief and before a [three-judge] court by way of the injunction route. It is also theoretically possible for different results to emerge from the separate trial courts. ... It is [also] possible that two separate appellate courts can simultaneously have before them identical issues. . . .

Such an extravagant expenditure of judicial resources on the same issue for the benefit of the same plaintiff is "particularly pernicious." Id. at 846 . 
States." When asked to enjoin the enforcement of state statutes, the Supreme Court has shown great respect for these principles. ${ }^{69}$

Where the declaratory judgment is available as an alternative remedy for the protection of constitutional rights, the denial of a permanent injunction does not expose the plaintiff to any danger of irreparable injury. The losing party nearly always heeds the declaration; ${ }^{70}$ in the rare case when he does not, the prevailing party can request a prelimjnary injunction pending appeal or a permanent injunction after appellate review. ${ }^{21}$ In either instance, collateral review of the constitu-

68. Younger v. Harris, 401 U.S. 37, 44 (1971) (reversing a grant of an injunction restraining a pending state criminal prosecution).

69. E.g., Rizzo v. Goode, 96 S. Ct. 598, 608 (1976) (reversing a grant of a mandatory injunction ordering implementation of a comprehensive program to improve procedures for handling citizen complaints of police misconduct) (alternative holding):

Thus the principles of federalism which play such an important part in governing the relationship between federal courts and state governments, though initially expounded and perhaps entitled to their greatest weight in [attempts] to enjoin a criminal prosecution in progress, have not been limited either to that situation or indeed to a criminal proceeding itself. We think these principles likewise have applicability where injunctive relief is sought not against the judicial branch of the state government, but against those in charge of an executive branch of an agency of state or local governments ....

For other examples, see Younger v. Harris, 401 U.S. 37, 43.44 (1971); Railroad Comm'n v. Pullman Co., 312 U.S. 496, 500-01 (1941) (reversing a grant of an injunction against the enforcement of a state railroad regulation to allow the issues of state law to be adjudicated in a state forum) (citations omitted):

Few public interests have a higher claim upon the discretion of a federal chancellor than the avoidance of needless friction with state policies, whether the policy relates to the enforcement of the criminal law, or the administration of a specialized scheme for liquidating embarrassed business enterprises, or the final authority of a state court to interpret doubtful regulatory laws of the state. These cases reflect a doctrine of abstention appropriate to our federal system whereby the federal courts, "exercising a wise discretion," restrain their authority because of "scrupulous regard for the rightful independence of the state governments" and for the smooth working of the federal judiciary.

See generally HART AND WECHSLER, supra note 1, at 985-1050.

70. ALI STUdy, supra note 13, at 323:

[V]oluntary compliance with the orders of federal courts is the norm and the desideratum and this is as true of declaratory judgments as of injunctive orders. A state is not likely to seek to enforce a statute that has been solemnly declared unconstitutional.

E. Borchard, Declaratory Judgments 12 (2d ed. 1941): "The display of force is quite unnecessary to give effect to the [declaratory judgment]. The more highly organized a society becomes, the less occasion there is to display force in order to secure obedience to its decrees and adjudications." Id. at 439 (footnote omitted): "The declaration is an authoritative adjudication and guide to conduct, and rarely, so far as records disclose, has it become necessary again to invoke the aid of the court to carry a declaratory judgment into forceful effect." See Mitchell v. Donovan, 398 U.S. 427, 433 (1970) (Douglas, J., dissenting) ("The declaratory judgment may well contain a 'thou shalt not' as commanding as any injunction."); Dickson, Declaratory Remedies and Constitutional Change, 24 VAND. L. REv. 257, 260 (1971).

71. 28 U.S.C. $\$ 2202$ empowers a federal court to grant "[f]urther necessary or proper relief based on a declaratory judgment." If the defendant refuses to act in accordance with the declaration of rights after the declaration has been affirmed on appeal, an in- 
tional issues is foreclosed, ${ }^{2}$ and a single judge may grant the relief required to enforce the rights already declared. ${ }^{73}$ The substitution of declaratory for permanent injunctive relief does not put the plaintiff at a significant disadvantage pending appeal. If declaratory relief is granted, the plaintiff may apply for an enforcing injunction, while if permanent injunctive relief is granted, the state may apply for a stay. The court will consider the same factors in ruling on either request. ${ }^{74}$

The declaratory judgment is not only an adequate substitute for a permanent injunction; it is also fundamentally better suited to the invalidation of unconstitutional state statutes. When a federal court declares constitutional rights under a challenged statute, it does not, in the first instance, command compliance with that declaration under threat of contempt. If compliance with a declaration of unconstitutionality would substantially disrupt state affairs or would intrude in particularly sensitive areas, the state may choose not to recognize it pending review by an appellate court. Only when the plaintiff initiates and prevails in an action for a preliminary injunction pending appeal must the state recognize the declaration. Moreover, the plaintiff carries the burden of persuasion in such an action, while if the court grants a permanent injunction, the state bears the burden of obtaining a stay of the injunction pending appeal.

Except for this shift in the burden of obtaining compliance with the order pending appeal, the eventual legal effect on the states of a declaratory judgment is identical to that of a permanent injunction.

junction becomes both "necessary" and "proper" under $\$ 2202$; without it the declaratory judgment would be an unenforceable advisory opinion. Pending appeal, a court may similarly find a temporary injunction necessary and proper.

72. The declaratory judgment would estop the defendant from relitigating the con. stitutional issues in an ancillary procceding to enforce that judgment. King v. United States, 390 F.2d 894, 906 (Ct. Cl. 1968), rev'd on other grounds, 395 U.S. 1 (1969) (“Declarations have, by [28 U.S.C. $\$ 2201]$, "the force and effect of a final judgment or decree' and, thereforc, collatcrally estop the litigants from retrying isstes.") (dictum). But see Currie, supra note 1 , at $18 \mathrm{n} .102$ (arguing for an exception to "the presailing federal rule that ordinarily a declaratory judgment is res judicata pending appeal").

73. It might be argued that an injunction to enforce a declaratory judgment affirmed on appeal rests on the constitutional determination underlying the declaratory judgment, and hence that the injunction is granted "upon the ground of the unconstitutionalit)" of a state statute. Even if this argument is accepted, $\$ 2281$ does not require a thrcejudge court to issue the enforcing injunction. Goosby v. Osser, 409 U.S. 512,513 (197:), held that when "prior decisions inescapably render the [constitutional] claims frivolous," a three-judge court is not required. The declaratory judgment is a "prior decision" which renders any constitutional claims frivolous in the subsequent hearing on the injunction.

But see Currie, supra note 1 , at $17-19 \&$ n.102 (arguing that to allow a single judge to grant an injunction in support of a declaratory judgment would undermine the policy of the three-judge court statute).

74. Compare 7 Moore's Federal Practice $\$$ 62.05, at $24-26$ (2d cd. 1975) (stay) with id. $\{65.04[1]$, at $39-47$ (preliminary injunction). 
Nevertheless, the manner of intrusion by declaratory judgment is preferable for review of state legislation. For a lower federal court to declare constitutional rights and presume good-faith compliance shows more respect for state sovereignty than to threaten state officers with contempt sanctions before they have had an opportunity to comply.

The legislative history of the Declaratory Judgment Act supports the view of the declaratory judgment as a preferred alternative to the injunction when state legislation is challenged on constitutional grounds. ${ }^{75}$ Because the declaratory judgment "is not followed . . . by immediately coercive relief," Congress expected it to obviate "much of the hostility to the extensive use of the injunction power by the federal courts." 76 The Senate Report noted that the declaratory judgment had proved so "necessary" that "in many cases the injunction procedure [had been] abused in order to render . . . in effect a declaratory judgment." $\mathrm{i} \tau$

In construing the three-judge court statutes, the Supreme Court has relied on the less disruptive nature of declaratory relief. ${ }^{78}$ In Kennedy v. Mendoza-Martinez, the Court stated that the declaratory judgment below affected the Government "in a totally noncoercive fashion."78 The Court reasoned that "[p]ending review in the Court of Appeals, and in this Court, the Government has been free to continue to apply the statute"; hence, unlike the situation where an injunction has been issued, "the operation of the statutory scheme [was not] immediately disrupted." $s 0$

More recently, in Steffel $v$. Thompson the Court recognized the "less intrusive effect [of the declaratory judgment] on the administration of state criminal laws." 11 The Court held unanimously that

75. For a discussion of the legislative history of the Declaratory Judgment Act, see Justice Brennan's concurrence in Perez v. Ledesma, 401 U.S. 82, 111-15 (1971). Writing for the Court in Steffel v. Thompson, 415 U.S. 452, 466-72 (1974), Justice Brennan drew heavily on his Perez concurrence; he stated that

Congress plainly intended declaratory relief to act as an alternative to the strong medicine of the injunction and to be utilized to test the constitutionality of state criminal statutes in cases where injunctive relief would be unavailable. . .

Id. at 466.

76. S. ReP. No. 1005, 73d Cong., 2d Sess. 2-3 (1934).

77. Id. at 3 .

78. Kennedy v. Mendoza-Martinez, 372 U.S. 144, 155 (1963) (\$ 2282, the federal counterpart to $\$ 2281$, does not bar single judge from hearing action for declaratory relief where injunctive relief was not contemplated); see Mitchell v. Donovan, 398 U.S. 427, 430-31 (1970) (finding a distinction between a declaratory judgment and an injunction for purposes of allowing direct review of the determination of a three-judge court convened under $\$ 2282)$.

79. 372 U.S. 144, 155 (1963).

80. Id.

81. 415 U.S. 452,469 (1974). 
even where an injunction against a threatened state criminal proceeding would be inappropriate, federal declaratory relief was not precluded. ${ }^{82}$ For an important category of constitutional challenges to state statutes, then, the Court has elevated the declaratory judgment to a preferred position over the injunction.

In earlier cases, courts simply have acted on this preference for the declaratory judgment under the assumption that the state would comply with a declaration of constitutional rights. ${ }^{\$ 3}$ In Roe v. Wade, for example, the Court found it "unnecessary to decide whether the District Court erred in withholding injunctive relief, for we assume the Texas prosecutorial authorities will give full credence" to the declaratory judgment. ${ }^{84}$ In Rodriguez $v$. San Antonio Independent School District, the three-judge court declared unconstitutional the Texas system of financing public education, and enjoined the state from giving effect to the state provisions on which the school financing system was based; however, it stayed the injunction for two years to give the state legislature an opportunity to comply with the declaration. $^{85}$ And in Catholic Medical Center $v$. Rockefeller, the three-judge court granted a declaratory judgment, but refused to issue a mandatory injunction directing payments by state officers:

Plaintiffs' request for an injunction presents questions of the effectiveness and necessity of that remedy .... [,] an extreme

82. Id. at 471-72. In Samuels v. Mackell, 401 U.S. 66 (1971), the Court held that a three-judge court should have dismissed requests for a declaratory judgment against a state criminal statute and for an injunction restraining the enforcement of the statute, because a state prosecution under the statute was pending. The Court reasoned that "ordinarily a declaratory judgment will result in precisely the same interference with and disruption of state proceedings" as an injunction, and hence that "with respect to the limited question [of] cases where the criminal proceding was begun prior to the civil stit, the propricty of declaratory and injunctive relief should be judged by essentially the same standards." Id. at 72. Steffel expressly reaffirmed that Samucls is limited to cases where a state criminal proceeding is pending. 415 U.S. at $460.61,475$.

83. E.g., Roc v. Wade, 410 U.S. 113 (1973); Doc v. Bolton, 410 U.S. 179 (1973); Thoms v. Smith, 334 F. Supp. 1203, 1211 (D. Conn. 1971), rev'd on other grounds, 418 U.S. 908 (1974) ("We have no reason to believe defendants will continue to enforce the [statute] upon notice of this decision; accordingly, we forebear to enter an injunction restraining them from enforcing it."); Rodriguez v. San Antonio Indep. School Dist., 337 F. Supp. 280 (W.D. 'Tex. 1972), rev'd on other grounds, 411 U.S. I (1973); Catholic Medical Center r. Rockefeller, 305 F. Supp. 1268 (E.D.N.Y. 1969), racated, 397 U.S. 820, appeal dismissed, 400 U.S. 931 (1970); University Comm. to End the War in Vietnam v. Gunn, 289 F. Supp. 469,475 (W.D. Tex. 1968), appeal dismissed, 399 U.S. $383(1970)$. In Gunn, a three-judge court granted declaratory and injunctive relief, but ordered that the "mandate shall be stayed" pending the next session of the Texas legislature. The three-judge court did not make clear whether it meant to stay the declaratory judgment as well as the injunction, see 399 U.S. at 387, 389-90, but "the opinion of the District Court should be viewed as having the operative effect of a declaratory judgment invalidating the Texas statute. . ." Id. at 391 (White, J., concurring).

84. Roe v. Wade, 410 U.S. 113,166 (1973).

85. 337 F. Supp. 280, 286 (W.D. Tex. 1972), rev'd on other grounds, 411 U.S. 1 (1973). 
Judicial Limitation of Three-Judge Court Jurisdiction

exercise of federal judicial power. ... [T] he court may assume that [the state] will abide by a judicial declaration of rights without having to be compelled to do so by injunction. Relief by way of declaratory judgment should meet the situation adequately. If further state action is unreasonably delayed, plaintiffs may apply for supplemental injunctive relief. . . .s6

Cases such as Roe, Rodriguez, and Catholic Medical Center, in which declaratory relief was found adequate even though injunctive relief was also requested, were decided by three-judge courts. Under the analysis of Part II of this Note, such cases could have been decided by a single judge. The single judge may-and should-dispose of all issues in a constitutional challenge to a state statute except the question of preliminary injunctive relief. For the single judge to exercise this power would promote "the smooth working of the federal judiciary" 87 and show deference to state sovereignty, without undermining the protection of constitutional rights.

86. 305 F. Supp. 1268, 1270-71 (E.D.N.Y. 1969), vacated, 397 U.S. 820, appeal dismissed, 400 U.S. 931 (1970).

87. Railroad Comm'n v. Pullman Co., 312 U.S. 496, 501 (1941) (Frankfurter, J.). 